\title{
The prevalence of mesiodens in orthodontic patients in western region of Nepal
}

\author{
Anjana Karmacharya ${ }^{1}$, Dashrath Kafle ${ }^{2}$ \\ ${ }^{1}$ Lecturer, Department of Dentistry, Manipal Teaching Hospital, Pokhara, Nepal, ${ }^{2}$ Associate Professor, Department of \\ Dentistry, Dhulikhel Hospital, Kathmandu, Nepal
}

Background: Mesiodens are supernumerary teeth present in the midline of the maxilla. Aims and Objective: The present study was conducted to know the prevalence of mesiodens among children aged 5 to 14 years in Pokhara, Nepal. Materials and Methods: Data was collected from 1194 orthodontic patients coming to the department of Dentistry, in Manipal Teaching Hospital from 2009 till 2019. The files were reviewed to know the prevalence, demography and the complications associated with the presence of mesiodens. Results: Our results showed that the prevalence of mesiodens was $2.84 \%$ in our population. The prevalence was significantly more among males. Children aged 10-14 years presented more than the children aged 5-10 years. Though, there were complications associated with the presence of mesiodens, none of them were symptomatic. Conclusions: Mesiodens is the most common form of supernumerary teeth in the pediatric patients which occurs as a result of genetic and environmental factors. Their early diagnosis can reduce the treatment required and therefore prevent development of associated problems in the future.

Key words: Mesiodens; Nepal; Prevalence

\section{Access this article online}

Website:

http://nepjol.info/index.php/AJMS

DOI: 10.3126/ajms.v12i9.37304

E-ISSN: 2091-0576

P-ISSN: 2467-9100

Copyright (c) 2021 Asian Journal of Medical Sciences

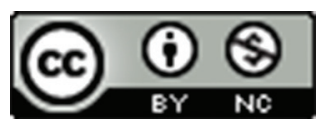

This work is licensed under a Creative Commons Attribution-NonCommercial 4.0 International License.

\section{INTRODUCTION}

Mesiodens are supernumerary tooth present in the palatal midline between the two maxillary central incisors. These supernumerary tooth are developmental anomaly where there is the presence of an extra tooth to the normal dentition of the maxilla. ${ }^{1,2}$ They are typically present in the midline of the premaxilla, where embryogenesis differs from the other facial bones, thus the possible deviations in the premaxillary region. These deviations can lead to the development of additional teeth and other abnormalities. Though the etiology of mesiodens tooth is not clearly known; there are few theories to explain their occurrence. ${ }^{3}$ Some authors relate them to genetic and environmental factors, ${ }^{4,5}$ whereas some suggests that the tooth bud is split to create two teeth, one of which is the mesiodens. ${ }^{6}$ But the most widely supported theory explains it as the hyperactivity of the dental lamina. ${ }^{7}$ According to this theory, remnants of the dental lamina or palatal offshoots of the active dental lamina are induced to develop into an extra tooth bud, which results in a supernumerary tooth. It has also been associated with some syndromes like Gardner's syndrome, Cleft lip and palate and Cleidocranial dysplasia. ${ }^{8}$

The prevalence of mesiodens varies between 0.15 and $3.8 \%$ of the population, ${ }^{1,9}$ whereas other studies reported them to be between 0.09 and $2.05 \% .{ }^{10-12}$ Mesiodens have been reported to be more common in males than in females. ${ }^{13}$ Some literatures reports that 80 to $90 \%$ of all supernumerary teeth occurs in the maxilla, out of which half are found in the anterior region..$^{14,15}$

Mesiodens can be classified depending on their number, position and morphology. Among the various types of mesiodens the most common type is supernumerary 
tooth. ${ }^{3}$ Based on the morphology, they can be classified as supplemental, conical and tuberculate type. ${ }^{7,9}$ The complications associated with a Mesiodens may include crowding, impaction, diastema, delayed and or ectopic eruption of adjacent teeth, axial rotation and displacement, dentigerous cyst and radicular resorption of adjacent teeth. ${ }^{710-14}$ This study was conducted to determine the prevalence rate of mesiodens in orthodontic patients in western region of Nepal.

\section{MATERIALS AND METHODS}

Data for the study was collected retrospectively through out-patient registers, recording clinical evaluation of children visiting the out-patient department (OPD) of Manipal Teaching Hospital, Pokhara, Nepal. The records of clinical examination of the patients who attended the OPD from the year 2009 to 2019 were evaluated. Consent to evaluate the file records was obtained from the Ethical Board of the Hospital. The records indicating the clinical presence of mesiodens was noted. The patients were divided into two groups- Junior (5 to 10 years) and Senior (11 to 14 years). The patient's data was collected for gender, the number of mesiodens, erupted or unerupted, position and any associated complications due to the presence of the mesiodens. Data analysis was performed using SPSS (IBM, Chicago, Il.). Frequency distributions were produced. Pearson's chi square test with Cramer's V was used as a test of association. $\mathrm{P}$ value less than 0.05 was considered significant.

\section{RESULTS}

There were a total of 1194 children aged between 5 to 14 years who presented to our hospital for orthodontic treatment from 2009 to 2019. There were 324 females $(27.13 \%)$ and 870 males $(72.87 \%)$. There were more children in the senior group ( $\mathrm{n}=682,57.11 \%)$ than the junior group ( $\mathrm{n}=512,42.89 \%$ ) in our study (Table 1). The overall prevalence of mesiodens was $2.84 \%(n=34)$. Age was significantly associated with the presence of mesiodens $(\chi(1)=4.737, \mathrm{p}=0.03)$ with higher number in the seniors $(\mathrm{n}=21,1.75 \%)$ as compared to the juniors $(\mathrm{n}=13,1.08 \%)$. Similarly, gender was significantly associated with presence of mesiodens $(\chi(1)=4.445, \mathrm{p}=0.035)$ where higher number of males $(n=24,2.01 \%)$ presented with mesiodens than females ( $\mathrm{n}=10,0.83 \%)$. However, in both the analysis, the association was weak ( $\phi c=0.037$ and $\phi c=0.036$, respectively). The number of single mesiodens $(n=26$, $76.47 \%$ ) was more than double mesiodens ( $\mathrm{n}=8,23.53 \%$ ) in our study. Similarly, the number of erupted mesiodens $(\mathrm{n}=26,76.47 \%)$ was more than unerupted mesiodens $(\mathrm{n}=8$, $23.53 \%$ ) in our study. The initial position of mesiodens at the time of diagnosis was mostly seen in between the two upper central incisors $(n=22)$, followed by impacted in between the roots of central incisors $(n=7)$, palatally $(n=4)$ and labially $(\mathrm{n}=1)$. Based on the shape of the mesiodens, conical mesiodens ( $\mathrm{n}=19,55.88 \%$ ) was commoner in our study as compared to tubular ( $\mathrm{n}=15,44.12 \%)$.

Though there were complications associated with the presence of mesiodens, none of the children was symptomatic i.e there was no pain or swelling at the site of mesiodens. Among the complications associated with the presence of mesiodens, diastema was the commonest $(\mathrm{n}=19,55.90 \%)$. Others include mesial tipping of erupted permanent incisors $(\mathrm{n}=6,17.64 \%)$, rotations $(\mathrm{n}=6$, $17.64 \%)$, root anomaly (dilaceration) ( $\mathrm{n}=2,5.88 \%)$ and root resorption of teeth adjacent to mesiodens $(\mathrm{n}=1$, $2.94 \%$ ) (Table 2).

\section{DISCUSSION}

Similar to other studies, the prevalence of mesiodens was higher among males than females. ${ }^{9} 15-17$ Unlike the study by Narayan ${ }^{16}$ where junior age group were found to have higher reported occurrence of mesiodens, our studies had

\begin{tabular}{|c|c|c|c|}
\hline Variables & & $\begin{array}{c}\text { Number of } \\
\text { patients }\end{array}$ & Percentage \\
\hline $\begin{array}{l}\text { Total } \\
\text { patient }\end{array}$ & & 34 of 1194 & $2.84 \%$ \\
\hline \multirow[t]{2}{*}{ Sex } & Male & 870 & $72.87 \%$ \\
\hline & Female & 324 & $27.13 \%$ \\
\hline \multirow[t]{2}{*}{ Age } & Junior (5-10 years) & 512 & $42.89 \%$ \\
\hline & Senior (10-14 years) & 682 & $57.11 \%$ \\
\hline \multirow{8}{*}{$\begin{array}{l}\text { Number of } \\
\text { mesiodens } \\
\text { Eruption } \\
\text { status } \\
\text { Initial } \\
\text { position }\end{array}$} & Single & 26 & $76.47 \%$ \\
\hline & Double & 8 & $23.53 \%$ \\
\hline & Erupted & 26 & $76.47 \%$ \\
\hline & Unerupted & 8 & $23.53 \%$ \\
\hline & $\begin{array}{l}\text { between the two } \\
\text { upper central incisors }\end{array}$ & 22 & $64.70 \%$ \\
\hline & $\begin{array}{l}\text { between the roots of } \\
\text { central incisors }\end{array}$ & 7 & $20.6 \%$ \\
\hline & palatally & 4 & $11.76 \%$ \\
\hline & labially & 1 & $2.94 \%$ \\
\hline
\end{tabular}

\begin{tabular}{lcc}
$\begin{array}{l}\text { Table 2: Complications associated with } \\
\text { mesiodens }\end{array}$ & \\
\hline Complications & Number of patients & Percentage \\
\hline $\begin{array}{l}\text { Diastema } \\
\text { mesial tipping of erupted }\end{array}$ & 19 & $55.90 \%$ \\
$\begin{array}{l}\text { permanent incisors } \\
\text { rotations } \\
\text { root anomaly (dilaceration) } \\
\text { root resorption of teeth } \\
\text { adjacent to mesiodens }\end{array}$ & 6 & $17.64 \%$ \\
\hline
\end{tabular}


more cases of mesiodens in the senior group. Our study reports $2.84 \%$ of children aged between 5 to 14 to have mesiodens which was comparable to other studies where prevalence ranged from $0.6 \%$ to $3.18 \%{ }^{16-18}$ In $80-90 \%$ of the patients the mesiodens occurs in the maxilla with majority in the anterior region. ${ }^{12,15}$

In our study majority of mesiodens $(57.11 \%)$ was found in senior age group of 10-14 years. This finding was in similar to other studies. ${ }^{14,19-21}$ Unlike the study by Mukhopadhyay, where they found the incidence of unerupted mesiodens to be higher (53.9\%), our study had more erupted mesiodens (76.47\%). Similar to other studies, the most common complications associated with mesiodens in our study was diastema., ${ }^{9,16}$

\section{CONCLUSIONS}

Mesiodens is the most common form of supernumerary teeth in the pediatric patients which occurs as a result of genetic and environmental factors. Mesiodens are common among male children aged between 10 to 14 years. Their early diagnosis can reduce the treatment required and therefore prevent development of associated problems in the future.

\section{REFERENCES}

1. Liu JF. Characteristics of premaxillary supernumerary teeth: a survey of 112 cases. ASDC J Dent Child. 1995; 62(4):262-265.

2. Alberti G, Mondani PM and Parodi V. Eruption of supernumerary permanent teeth in a sample of urban primary school population in Genoa, Italy. Eur J Paediatr Dent Off J Eur Acad Paediatr Dent. 2006; 7(2):89-92.

3. Stellzig A, Basdra EK and Komposch G. Mesiodentes: incidence, morphology, etiology. J Orofac Orthop Fortschritte Kieferorthopädie OrganOfficial J Dtsch Ges Für Kieferorthopädie. 1997; 58(3):144-153.

https://doi.org/10.1007/BF02676545

4. Townsend GC, Richards L, Hughes T, Pinkerton S and Schwerdt W. Epigenetic influences may explain dental differences in monozygotic twin pairs. Aust Dent J. 2005; 50(2):95-100. https://doi.org/10.1111/j.1834-7819.2005.tb00347.x

5. Orhan Al, Ozer $L$ and Orhan K. Familial occurrence of nonsyndromal multiple supernumerary teeth. A rare condition. Angle Orthod. 2006; 76(5):891-897.

6. Sedano $\mathrm{HO}$ and Gorlin RJ. Familial occurrence of mesiodens. Oral Surg Oral Med Oral Pathol. 1969; 27(3):360-361. https://doi.org/10.1016/0030-4220(69)90366-1
7. Primosch RE. Anterior supernumerary teeth--assessment and surgical intervention in children. Pediatr Dent. 1981; 3(2):204-215.

8. Nazif MM, Ruffalo RC and Zullo T. Impacted supernumerary teeth: a survey of 50 cases. J Am Dent Assoc. 1983; 106(2):201-204. https://doi.org/10.14219/jada.archive.1983.0390

9. Mukhopadhyay S. Mesiodens: a clinical and radiographic study in children. J Indian Soc Pedod Prev Dent. 2011; 29(1):34-38. https://doi.org/10.4103/0970-4388.79928

10. Hattab FN, Yassin OM and Rawashdeh MA. Supernumerary teeth: report of three cases and review of the literature. ASDC J Dent Child. 1994; 61(5-6):382-393.

11. Brook $\mathrm{AH}$. Dental anomalies of number, form and size: their prevalence in British schoolchildren. J Int Assoc Dent Child. 1974; 5(2):37-53.

12. Ray D, Bhattacharya B, Sarkar S and Das G. Erupted maxillary conical mesiodens in deciduous dentition in a Bengali girl--a case report. J Indian Soc Pedod Prev Dent. 2005; 23(3):153-155. https://doi.org/10.4103/0970-4388.16891

13. Leco Berrocal MI, Martín Morales JF and Martínez González JM. An observational study of the frequency of supernumerary teeth in a population of 2000 patients. Med Oral Patol Oral Cir Bucal. 2007; 12(2): E134-E138.

14. Garvey MT, Barry HJ and Blake M. Supernumerary teeth--an overview of classification, diagnosis and management. J Can Dent Assoc. 1999; 65(11):612-616.

15. Zhu JF, Marcushamer M, King DL and Henry RJ. Supernumerary and congenitally absent teeth: a literature review. J Clin Pediatr Dent. 1996; 20(2):87-95.

16. Narayan JP and Kumari N. Prevalence of mesiodens in five to fourteen year old children in Balidih, Jharkhand, India. International Journal of Medical and Health Research. 2019;5(1):254-256.

17. Khandelwal V, Nayak AU, Naveen RB, Ninawe N, Nayak PA and Sai Prasad SV. Prevalence of mesiodens among six- to seventeen-year-old school going children of Indore. J Indian Soc Pedod Prev Dent. 2011; 29(4):288-293. https://doi.org/10.4103/0970-4388.86369

18. Ferrés-Padró $E$, Prats-Armengol $J$ and Ferrés-Amat $E$. A descriptive study of 113 unerupted supernumerary teeth in 79 pediatric patients in Barcelona. Med Oral Patol Oral Cir Bucal. 2009; 14(3): E146-E152.

19. Gündüz K, Celenk $P$, Zengin $Z$ and Sümer P. Mesiodens: $a$ radiographic study in children. J Oral Sci. 2008; 50(3):287-291. https://doi.org/10.2334/josnusd.50.287

20. Kazanci F, Celikoglu M, Miloglu O, Yildirim H and Ceylan I. The frequency and characteristics of mesiodens in a Turkish patient population. Eur J Dent. 2011; 5(3):361-365. https://doi.org/10.1055/s-0039-1698906

21. Nagaveni NB, Sreedevi B, Praveen BS, Praveen Reddy B, Vidyullatha BG and Umashankara KV. Survey of mesiodens and its characteristics in 2500 children of Davangere city, India. Eur J Paediatr Dent Off J Eur Acad Paediatr Dent. 2010; 11(4):185-188.

\footnotetext{
Authors Contribution:

AK - Concept and design, review of literature, statistically analysis and interpretation, manuscript preparation and revision; DK - Data collection and manuscript revision.

Work attributed to:

Department of Dentistry, Manipal Teaching Hospital, Phulbari, Pokhara, Nepal.

Orcid ID:

Dr. Anjana Karmacharya - (i) https://orcid.org/0000-0002-7672-4131

Dr. Dashrath Kafle - (1) https://orcid.org/0000-0003-2207-6842

Source of Support: Nil, Conflict of Interest: None declared.
} 